\title{
ASSESSMENT OF THE GENETIC RELATIONSHIPS BETWEEN UDDER HEALTH AND MILK TRAITS PRODUCTION IN RELATION TO SELECTION FOR IMPROVING RESISTANCE TO MASTITIS IN FRIESIAN COWS IN EGYPT
}

El-Arian M. N. ${ }^{1}$ and H. G. El-Awady ${ }^{2}$

1- Animal Production Dept., Fac. of Agric., Mansoura Univ., Egypt

2- Animal Production Dept., Fac. of Agric., Kafrelsheikh Univ., Egypt

E-mail: mnelarian@yahoo.com

\begin{abstract}
Genetic parameters were estimated by multitrait REML programme using an animal model for udder health traits [clinical mastitis (MAST) and somatic cell counts (SCC)] and milk yield traits [305day milk yield (MY), 305day fat yield (FY) and 305day protein yield (PY)] in the first three lactations of 4015 Friesian cows records calved first from 2000 to 2005 at Sakha farm. The mixed model used in the analysis included the fixed effects of month and year of calving, and parity and the random effects of additive genetics, maternal permanent environment and residual. For each lactation, heritability estimates for MAST $(0.13$ to 0.20$)$ were slightly higher than those for SCC (0.08 to 0.15 ) and were from 0.21 to 0.35 for milk yield traits. Heritability estimates for all lactations were $0.21,0.11,0.33,0.29$ and 0.29 for MAST ,SCC ,MY,FY and PY ,respectively. The genetic correlations between MAST and SCC being 0.72 for $1^{\text {st }}$, 0.79 for $2^{\text {nd }}$ and 0.83 for $3^{\text {rd }}$ lactations indicated that both traits were genetically favorably associated and selection for low SCC will reduce the incidence of mastitis. The genetic correlations between udder health traits and milk yield traits were mildly positive ( 0.27 to 0.55 ) confirming a genetic antagonism between production and udder health traits in this herd. Genetic correlations for each trait across lactations were positive and high for all traits studied, MAST (0.70 to 0.93), SCC (0.84 to 0.91) and milk traits $(0.88$ to 0.99$)$. The strongest correlations were between second and third lactation for all investigated traits. The positively high genetic correlations between both MAST and SCC in subsequent lactations suggested that susceptibility to mastitis remains unchangeable by advanced of age. For all lactations, genetic correlations were slightly lower than subsequent lactations. Estimates of permanent environmental variances as proportions of phenotypic variances were, 0.09, 0.39, 0.11, 0.22 and 0.23 for MAST, SCC, MY, FY and PY, respectively.

Selection of the cow on the basis of their expected breeding values should cause reduction in the incidence MAST and SCC, and increase MY, FY and PY. The accuracy of the index that included SCC and MAST with MY was about 7 times higher than that of other indices. It is emergent to include udder health traits in the breeding programme by using SCC as a criterion for selection for mastitis resistance.

Keywords: heritability, genetic and phenotypic correlation, somatic cell count, mastitis, mastitis resistance, expected breeding value and selection index.
\end{abstract}

\section{INTRODUCTION}

Mastitis is one of the most costly common diseases in dairy cattle. Strategies to reduce mastitis are essential for decreasing costs and improving the quality of production. Moreover, it causes the cows to suffer and for ethical and animal welfare reasons (Koivula et al., 2005). It is important to consider mastitis in dairy cattle breeding programmes. Mastitis and high 
somatic cell counts (SCC) were the second leading reason for culling and accounted for nearly $24 \%$ of culled cows (Svensk Miölk, 2002). Selection has traditionally focused on production traits and direct selection for resistant mastitis has been considered inefficient because the heritability of mastitis is low and most countries do not widely record clinical mastitis incidences (Mäntysaari, 1999, Carlén et al., 2004, and Koivula et al., 2005). Therefore, indirect measures of udder health such as SCC, have been an appealing alternative. SCC is routinely recorded in most milk recording systems, and information on SCC is easily available on a large scale. The efficiency of SCC as a selection criterion for mastitis resistance depends on its genetic correlation with the latter. Moderate to high positive genetic correlations $(0.6$ to 0.8) have been reported (Mäntysaari, 1999, Kadarmideen and Pryce, 2001, Carlén et al., 2004, and Koivula et al., 2005).

Elevation of SCC in milk samples is a clear indication of the udder infection. However, somatic cells are also present in milk of healthy cows and the increase in SCC is a normal cellular defense against udder infection. On the other hand, several studies reported that low lactation yield mean SCC does not increase the susptibility of cows to clinical mastitis (Rupp and Boichard, 2000, Rupp et al., 2000 and Boettcher et al., 2002). Thus, it is needed to recognize that while selection against cows with high SCC is supposed to reduce mastitis incidence, the dilemma is whether SCC should be decreased to the lowest possible level, or should not be lowered below some critical threshold (Koivula et al., 2005).

The aim of this study was to estimate the genetic relationship between udder health traits and milk production, to determine whether SCC can serve as efficient indicator of mastitis infection to evaluate the efficiency of including it in a selection criterion to increase mastitis resistance in dairy cows.

Data

\section{MATERIALS AND METHODS}

Data on udder health measured as incidence of clinical mastitis (MAST) and lactation somatic cell counts (SCC) and the production traits of 305day milk yield (MY), 305day fat yield (FY) and 305day protein yield (PY) were extracted from the Sakha milk recording unit of the Animal Production Research Institute (APRI), Ministry of Agriculture, Egypt. Data included records on the first three lactations of 330 Friesian cows calving between January 2000 and December 2005 (Table 1).

Cows were daughters of 53 sires. Average number of daughters per sire was 39. Artificial insemination ( $\mathrm{Al}$ ) was used at random. Heifers were served for the first time when reached 24 months of age or $350 \mathrm{~kg}$ of weight. Cows were usually served two months after postparturition. The cows were loosely housed in open sheds and were kept under controlled system of feeding and management practiced in the farm. Milk yield was recorded daily to the nearest $0.1 \mathrm{~kg}$.

Definition of traits

A case of mastitis (MAST) was the veterinary treated clinical mastitis either with or without teat injury at any time from calving to the end lactation 
or culling. Cows with mastitis coded by 1 and without coded by 0 . Somatic cell counts (SCC) was arithmetic mean of monthly SCC from calving to the end of lactation, expressed the $1000 \mathrm{cells} / \mathrm{ml}$. Production of milk, fat and protein yields $(\mathrm{kg})$ were based on completed 305-d lactations. Cows with lactation periods more than 330 days excluded.

Table (1): Structure of data, means, standard deviation and number of observations for production and udder health traits in the first three lactations of Friesian cows.

\begin{tabular}{|l|c|c|c|c|}
\hline \multicolumn{1}{|c|}{ lactation } & First & Second & Third & All $\geq \mathbf{3}$ \\
\cline { 2 - 5 } Trait & $\bar{X} \pm$ SD & $\bar{X} \pm$ SD & $\bar{X} \pm$ SD & $\bar{X} \pm$ SD \\
\hline MY & $4123 \pm 1032$ & $4540 \pm 1068$ & $4804 \pm 1008$ & $4038 \pm 1253$ \\
FY & $149 \pm 26$ & $160 \pm 27$ & $167 \pm 25$ & $138 \pm 49.2$ \\
PY & $96 \pm 15$ & $112 \pm 15$ & $129 \pm \mathbf{1 6}$ & $102 \pm 39.98$ \\
SCC & $351 \pm 179$ & $368 \pm 181$ & $412 \pm 196$ & $426 \pm 212$ \\
MAST & $14.91 \pm 0.06$ & $14.90 \pm 0.05$ & $14.95 \pm 0.06$ & $14.94 \pm 0.05$ \\
\hline No. of records & 1836 & 1212 & 1022 & 4015 \\
\hline No. infected & 181 & 142 & 149 & 861 \\
\hline \% infection & 9.9 & 11.7 & 14.6 & 21.5 \\
\hline Age at calving & 29.62 & 43.21 & 57.94 & \\
\hline
\end{tabular}

\section{Statistical analysis}

Data were first analyzed using least-squares analysis of variance in order to determine the fixed effects to be included in the model. The statistical model included month (1 to 12) and year (2000 to 2005) of calving, parity (1 to $\geq 3$ ) and stage of lactation (1 to 11). Stage of lactation was coded at 30-d intervals 1 for 0 to $30 \mathrm{~d}$ after calving, 2 for 31 to $60 \mathrm{~d}$..... etc. All effects being significant for all traits were included in the analytical model. Covariance components were estimated for univariate and bivariate analysis for all traits with derivative-free restricted maximum likelihood (REML) procedures using the MTDFREML program of Boldman et al., (1995). The basic multiple model was:

Where:

$$
Y=X \beta+Z d+W p_{e}+e
$$

$\mathbf{Y}$ is a vector of observations, $\boldsymbol{\beta}=$ is a vector of fixed effects with incidence matrix $X$.

d $\sim$ NID $\left(0, I_{c} \sigma^{2}{ }_{\text {pe }}\right)$ is a vector of direct additive genetic effect with incidence matrix Z, Pe $\sim$ NID $\left(\mathbf{0}, \mathbf{A} \boldsymbol{\sigma}_{\mathrm{d}}{ }_{\mathrm{d}}\right)$ is a vector of random maternal permanent environmental effects with incidence matrix W, and e NID (0, In $\sigma^{2}$ ) is a vector of random residual effects. Also, $\sigma^{2}{ }_{d}$ is the direct additive genetic variance, $\boldsymbol{\sigma}^{2} \mathrm{pe}$ is the maternal permanent environmental variance, $\boldsymbol{\sigma}^{2}$ e. is the residual variance (temporary environment), $\mathbf{A}$ is the additive relationship matrix, $\mathbf{I}_{\mathbf{c}}$ and $\mathbf{I}_{\mathbf{n}}$ are identity matrices of order equal to the number of maternal permanent environmental effects and the number of records, respectively.

Convergence reached when the simplex variance was less than $10^{-8}$ and then several extra rounds of iterations were executed to ensure that a 
global maximum was reached. Best linear unbiased prediction (BLUP) of estimated breeding values (EBV's) were calculated by back-solution using the MTDFREML programme for all animals in the pedigree file for multi-traits analysis. Selection index was used to compare the accuracy of selection for mastitis resistance when selection is based on SCC, MAST or combination of both along with MY. Accuracy was defined as the correlation between the true breeding value using genetic and phenotypic covariances estimated in the first lactation.

\section{RESULTS AND DISCUSSION}

\section{Basic statistics}

The overall means and standard deviations for different traits are presented in table (1). As expected, MY, FY and PY increased with parity and so did the corresponding standard deviations. Likewise, an increase in SCC and MAST with parity were observed. This is in agreement with results of Schutz et el, (1990), Haile-Mariam et al., (2001a), Carlén et al., (2004) and Koivula et al., (2005). The frequencies of MAST occurance were 9.9\%, $11.7 \%, 14.6 \%$ and $21.5 \%$ for first, second, third and all lactations, respectively. These results were in close agreement with those reported by Koivula et al., (2005),being $11.8 \%$ and $14.9 \%$ for first and second lactations, but were higher than $5.4 \%$ and $7.9 \%$ reported by Pösö and Mäntysaari (1996). However, our results for all lactations were lower than the $28.5 \%$ reported by (Rautala, 2002). The high ratio of infection in all lactations data was due to including the repeated incidences on the same cow.

\section{Genetic parameters \\ Heritabilities}

Estimates of heritabilities for traits included in this study are presented in Table (2) and (4). The estimates of heritability obtained for SCC were 0.15 , $0.11,0.08$ and 0.11 for first, second, third and all lactations and lie well in the range of 0.08 to 0.15 reported by Mrode et al., 1998, Koivula et al., 2004, Carlén et al., 2004 and Koivula et al., 2005). However, Mrode and Swanson (1996) reported heritability estimates for SCC between 0.05 and 0.47 , with weighted average $0.11 \pm 0.04$ and $0.11 \pm 0.06$ for first and second lactations, respectively. Also, estimates ranging from 0.08 to 0.19 were reported by Heringstad et al., 2000 and between 0.09 and 0.18 by Haile-Mariam et al., 2001b and Mrode and Swanson 2003. Banos and Shook (1990) and Carlén et al., (2004) reported that heritability of SCC decreased from 0.14 to 0.10 when parity increased from 1 to 3 . Whereas Da et al., (1992) reported an increase in heritability of SCC from 0.05 to 0.11 for the same parities.

Heritability estimates for MAST were considerably higher than those for SCC in first, second, third and all lactations $(0.20,0.16,0.15$ and 0.21$)$ and decreased with increasing lactation number. Similar results were reported by Carlén et al., (2004) and Koivula et al., (2005).

Low heritability estimates for clinical mastitis, ranging from 0.001 to 0.06 were reported by Rupp and Boichard, 1999, Hansen et al., 2002, Lassen et al., 2003, Carlén et al., 2004 and Koivula et al., 2005, but Pösö and Mäntysaari (1999) obtained higher estimates for lactation 2 and 3 in 
comparison with first lactation, whereas Nielsen et al., (1997) found no differences in estimates of different lactations.

Heritabilities of MY, FY and PY were moderate $(0.21$ to 0.35$)$ and increase with increasing lactation number from 1 to 3 (Table 2) and from 0.29 to 0.33 for all lactations (Table 4). The similar trend were reported by Carlén et al., (2004) and Koivula et al., (2005).

\section{Correlations}

\section{1-between udder health traits}

The SCC and MAST traits had strong positive genetic correlations, ranging from 0.72 to 0.83 with highest estimate found in the third lactation (Table 2). These estimates are similar to those reported by Pösö and Mäntysaari (1996), Carlén et al., (2004) and Koivula et al., (2005). Other estimates vary from moderate to high, with an average of 0.70 (Mrode and Swanson, 1996, Rupp and Boichard, 1999, Heringstad et al., 2000 and HaileMariam et al., 2001b), and estimates close to unity were also found (Lund et al., 1994).

Table (2): Heritability estimates (diagonal), genetic correlations(above diagonal) and phenotypic correlations (below diagonal) for MY, FY, PY, SCC and MAST in the first three lactations (1, 2 and 3) of Friesian cows.

\begin{tabular}{|c|c|c|c|c|c|}
\hline Trait & MY & FY & PY & SCC & MAST \\
\hline $\begin{array}{c}\text { MY } \\
1 \\
2 \\
3 \\
\end{array}$ & $\begin{array}{l}0.35 \pm 0.03 \\
0.28 \pm 0.02 \\
0.23 \pm 0.03\end{array}$ & $\begin{array}{l}0.66(0.06) \\
0.58(0.04) \\
0.52(0.03)\end{array}$ & $\begin{array}{l}0.88(0.05) \\
0.81(0.05) \\
0.72(0.05)\end{array}$ & $\begin{array}{l}0.33(0.03) \\
0.38(0.04) \\
0.43(0.04)\end{array}$ & $\begin{array}{l}0.50(0.05) \\
0.52(0.05) \\
0.55(0.04)\end{array}$ \\
\hline $\begin{array}{c}\text { FY } \\
1 \\
2 \\
3 \\
\end{array}$ & $\begin{array}{l}0.89 \\
0.87 \\
0.86 \\
\end{array}$ & $\begin{array}{l}0.31 \pm 0.03 \\
0.29 \pm 0.03 \\
0.22 \pm 0.02\end{array}$ & $\begin{array}{l}0.77(0.05) \\
0.74(0.04) \\
0.67(0.05)\end{array}$ & $\begin{array}{l}0.27(0.04) \\
0.29(0.03) \\
0.32(0.04)\end{array}$ & $\begin{array}{l}0.39(0.04) \\
0.41(0.04) \\
0.44(0.05)\end{array}$ \\
\hline $\begin{array}{c}\text { PY } \\
1 \\
2 \\
3 \\
\end{array}$ & $\begin{array}{l}0.98 \\
0.95 \\
0.91\end{array}$ & $\begin{array}{l}0.86 \\
0.85 \\
0.81\end{array}$ & $\begin{array}{l}0.29 \pm 0.01 \\
0.26 \pm 0.02 \\
0.21 \pm 0.01\end{array}$ & $\begin{array}{l}0.30(0.04) \\
0.35(0.03) \\
0.39(0.05)\end{array}$ & $\begin{array}{l}0.32(0.06) \\
0.39(0.05) \\
0.45(0.04)\end{array}$ \\
\hline $\begin{array}{c}\text { SCC } \\
1 \\
2 \\
3\end{array}$ & $\begin{array}{l}-0.25 \\
-0.23 \\
-0.18\end{array}$ & $\begin{array}{l}-0.47 \\
-0.43 \\
-0.33\end{array}$ & $\begin{array}{l}-0.19 \\
-0.15 \\
-0.11\end{array}$ & $\begin{array}{l}0.15 \pm 0.02 \\
0.11 \pm 0.03 \\
0.08 \pm 0.01\end{array}$ & $\begin{array}{l}0.72(0.07) \\
0.79(0.05) \\
0.83(0.07)\end{array}$ \\
\hline $\begin{array}{c}\text { MAST } \\
1 \\
2 \\
3 \\
\end{array}$ & $\begin{array}{l}-0.42 \\
-0.38 \\
-0.21\end{array}$ & $\begin{array}{l}-0.24 \\
-0.19 \\
-0.12\end{array}$ & $\begin{array}{l}-0.13 \\
-0.11 \\
-0.07 \\
\end{array}$ & $\begin{array}{l}0.63 \\
0.57 \\
0.59\end{array}$ & $\begin{array}{l}0.20 \pm 0.03 \\
0.16 \pm 0.02 \\
0.13 \pm 0.03\end{array}$ \\
\hline
\end{tabular}

S.E for phenotypic correlations ranged from 0.03 to $0.07,0.03$ to 0.08 and 0.02 to 0.09 for first, second and third lactation, respectively.

** $S$.E for genetic correlations are between parenthesis.

*** $1=$ first lactation, $2=$ second lactation and $3=$ third lactation.

Both genetic and phenotypic correlations in the present study, indicated that high SCC is genetically accompanied with low resistance to MAST infection and both are one expression of the udder health and hence SCC could serve as an indirect criterion of selection improve resistance to mastitis. 
The linear relationship between SCC and mastitis reported by Philipsson et al., (1995), Nash et al., (2000) and Koivula et al., (2005), confirmed the possibility of improving resistance to mastitis by selecting for low SCC. On the contrary, few researches have proposed a curvilinear relationship between the risk of mastitis and SCC, which means that the risk of mastitis increases if the SCC drops below some critical level (Kehrli and Shuster, 1994, and Peeler et al., 2003).

The genetic correlations between SCC across lactations ranged from 0.84 to 0.91 and between MAST, ranged from 0.71 to 0.93 (Table 3 ). The genetic correlations in all cases were much higher than the phenotypic correlations and those between the second and the third lactation were the higher. This suggested that susceptibility to MAST or the SCC remain consistent at the same level across lactations. Mrode and Swanson (1996) Pösö and Mäntysaari (1996), Boichard and Rupp, (1997), Nielsen et al., (1997), Mrode and Swanson (2003), Carlén et al., (2004) and Koivula et al., (2005) found similarly high positive genetic correlations across lactations for SCC.

Table (3): Estimates of genetic $\left(r_{g}\right)$ and phenotypic $\left(r_{p}\right)$ correlations between production and udder health traits across the first three lactations.

\begin{tabular}{|l|c|c|c|c|c|c|}
\hline \multirow{3}{*}{ Trait } & \multicolumn{7}{|c|}{ Correlations } \\
\cline { 2 - 7 } & \multicolumn{7}{|c|}{$\mathbf{r}_{\mathbf{g}}$} & $\mathbf{1}$ & $\mathbf{3}$ & $\mathbf{2}$ \\
\cline { 2 - 7 } & $\mathbf{1 - 2}$ & $\mathbf{1 - 3}$ & $\mathbf{2 - 3}$ & $\mathbf{1 - 2}$ & $\mathbf{1 - 3}$ & $\mathbf{2 - 3}$ \\
\hline MY & $0.91(0.03)$ & $0.91(0.04)$ & $0.95(0.05)$ & 0.61 & 0.66 & 0.56 \\
FY & $0.88(0.04)$ & $0.90(0.04)$ & $0.97(0.04)$ & 0.54 & 0.49 & 0.53 \\
PY & $0.94(0.04)$ & $0.94(0.03)$ & $0.99(0.05)$ & 0.51 & 0.51 & 0.60 \\
SCC & $0.87(0.05)$ & $0.84(0.04)$ & $0.91(0.05)$ & 0.60 & 0.47 & 0.55 \\
MAST & $0.80(0.04)$ & $0.74(0.03)$ & $0.93(0.04)$ & 0.34 & 0.31 & 0.31 \\
\hline
\end{tabular}

${ }^{*}$ S.E for genetic correlations are between parenthesis.

${ }^{\star *}$ S.E for phenotypic correlations ranged from 0.03 to 0.08 .

Table (4): Estimates of (Co)variance components for production (kg) and udder health traits in all lactations.

\begin{tabular}{|c|c|c|c|c|c|}
\hline \multirow{2}{*}{ Component } & \multicolumn{5}{|c|}{ Traits } \\
\hline & MY & $\mathbf{F Y}$ & PY & SCC & MAST \\
\hline & 12125.6 & 1905.9 & 1318.7 & 1582.1 & 1.20 \\
\hline$\sigma_{\mathrm{pe}}^{2}$ & 4138.7 & 1433.5 & 1058.3 & 5692.5 & 0.52 \\
\hline$\sigma_{e}^{2}$ & 21081.3 & 3242.6 & 2193.9 & 7203.4 & 3.94 \\
\hline$\sigma_{p}^{2}$ & 37345.6 & 6582.1 & 4570.9 & 14478.0 & 5.66 \\
\hline$h^{2}{ }_{a}^{2}$ & $0.33 \pm 0.08$ & $0.29 \pm 0.07$ & $0.29 \pm 0.09$ & $0.11 \pm 0.03$ & $0.21 \pm 0.05$ \\
\hline$c^{2}$ & 0.11 & 0.22 & 0.23 & 0.39 & 0.09 \\
\hline$e^{2}$ & 0.56 & 0.49 & 0.48 & 0.50 & 0.70 \\
\hline
\end{tabular}

$\sigma_{\mathrm{a}}^{2}=$ direct additive genetic variance, $\sigma_{\mathrm{pe}}^{2}=$ maternal permanent environmental variance, $\sigma^{2}{ }_{e}=$ residual, $\sigma_{p}^{2}=$ phenotypic variance, $h^{2}{ }_{a}=$ direct heritability, $c^{2}=$ fraction phenotypic variance due to permanent environmental effect and $e^{2}=$ fraction phenotypic variance due to residual effects.

\section{2- Between production traits}

Genetic correlations between milk production traits in the first three lactations were positive variety between 0.52 to 0.88 . The strength of these correlations declined with advancing lactations, especially those between milk and fat production. The phenotypic correlations for the same traits were all 
high and close to unity. Within lactations, the highest estimates were between first lactation milk and protein, but across lactations the highest genetic correlation was for protein between the $2^{\text {nd }}$ and $3^{\text {rd }}$ lactations (Table 3 ).

\section{3- between udder health traits and production traits}

Genetic correlations between all milk production traits and udder health traits were positive (Table 2) and increased with increasing parity. However, the magnitude of these correlations varied considerably between traits in different parities.

The highest estimate of genetic correlation was between udder health traits and production traits were in the third lactation. However, Carlén et al., (2004) reported that the highest genetic correlation between milk and MAST was found in the second lactation, while between SCC and milk production was found in the first lactation. But with respect to phenotypic correlations between udder health traits and milk production traits within parities small and negative estimates, ranging from -0.47 to -0.11 were obtained. This implies that mastitis incidence and the high SCC decrease milk production slightly. These results are in agreement with those reported by Mrode and Swanson 1996, Haile-Mariam et al., 2001b, Carlén et al., 2004 and Koivula et al., 2005. The genetic correlation between SCC and fat yield was lower than between SCC and milk or protein yield. Similarly were the results of Charfeddine et al., 1997, Rupp and Boichard, 1999, Castillo-Juarez et al., 2002 and Carlén et al., 2004. However, Banos and Shook, 1990, Pösö and Mäntysaari 1996 and Haile-Mariam et al., 2001a.reported that the genetic correlations between SCC and milk production, changed from positive in the first lactations, to negative in the later lactations.

Generally, the genetic association between incidence of mastitis and milk production traits is unfavorable and elevates with advancement of parity (Uribe et al., 1995, Nielsen et al., 1997, Heringstad et al., 1999, Rupp and Boichard, 1999 Heringstad et al., 2000, Hansen et al., 2002, Carlén et al., 2004 and Koivula et al., 2005).

Two alternatives available for explaining these changes: i) partly different genes affect SCC in first Vs. later lactations because different pathogens may be responsible for occurance of mastitis (Banos and Shook 1990). ii) culling practices, especially during first lactation remove lowproducing cows with high chance of occurance of mastitis and high level of SCC, but Carlén et al., (2004) expected no effect of culling practice on changes in genetic correlations.

\section{EBV and reliabilities}

Expected breeding values (EBV's) and reliability of estimates (R\%) for different traits are in Table (5). The highest EBV's for SCC were associated with those highest for mastitis. Weighted average EBV's for milk, fat and protein were $293 \mathrm{~kg}, 5.12 \mathrm{~kg}$ and $3.77 \mathrm{~kg}$ with reliabilities of $89 \%, 90 \%$, and $88 \%$, respectively. Whereas the EBV's for SCC and MAST were $-24.6 \times 10^{-3}$ cell $/ \mathrm{ml}$ and -0.09 with reliabilities of $85 \%$ and $84 \%$, respectively. 
Negative EBV's values mean that the daughters of a given sire have lower SCC or MAST than other sires and vice versed Koivula et al. (2005) indicated that the curvilinearity between MAST and SCC is caused by the nature of SCC as a mastitis infection indicator and seems to be a weak relationship for bulls with EBV's below the average because at the lower end of the curve, the slope seems to be much less, but for bulls with EBV's higher than average, the relationship becomes strong. However, Rupp and Boichard, 2000, Boettcher et al., 2002 and Carlén et al., 2004 noted no increase in susceptibility to clinical mastitis for cow with low SCC. Also, when the duration and severity of mastitis has been taken into account, it was observed that daughters of sires with transmitting abilities high for SCC have sever and long lasting clinical episodes (Nash et al., 2002 and Koivula et al., 2005). Furthermore, Rupp et al., (2000) and Koivula et al., (2005). suggested that cows with low mean SCC in the first lactation have also low risk for clinical mastitis in later lactations, thus, breeding goals should favor cows with low SCC.

The present results revealed that animals with genetically high SCC should be more vulnerable to mastitis and culling practices which remove low producing cows with high SCC, make the remaining cows enter their second and later lactations with low SCC, MAST and high milk yield. Therefore, the goal of reducing mastitis and its unfavorable genetic association with production and health should be taken into account.

Table (5): Expected breeding values (EBV's) and reliabilities of estimates $(R \%)$ for most common sires with large number of daughters for different traits studied.

\begin{tabular}{|c|c|c|c|c|c|c|c|c|c|c|c|}
\hline \multirow{3}{*}{$\underset{\text { ID }}{\text { Sire }}$} & \multirow{3}{*}{ ND } & \multicolumn{10}{|c|}{ Traits } \\
\hline & & \multicolumn{2}{|c|}{ MY } & \multicolumn{2}{|c|}{ FY } & \multicolumn{2}{|c|}{ PY } & \multicolumn{2}{|c|}{ SCC } & \multicolumn{2}{|c|}{ MAST } \\
\hline & & EBV & $\mathbf{R} \%$ & EBV & \begin{tabular}{|l|}
$R \%$ \\
\end{tabular} & EBV & $\mathbf{R} \%$ & EBV & $\mathbf{R} \%$ & EBV & $\mathbf{R} \%$ \\
\hline 100 & 423 & 295.1 & 94 & 4.24 & 94 & 3.33 & 93 & 18.57 & 91 & 0.005 & 88 \\
\hline & 304 & 377.3 & 94 & 5.86 & 92 & 4.71 & 94 & -30.3 & 94 & -0.026 & 85 \\
\hline 103 & 215 & 302.8 & 89 & 8.03 & 95 & 4.89 & 94 & -46.9 & 94 & -0.015 & 92 \\
\hline 11 & 203 & 418.2 & 96 & 7.26 & 97 & 4.53 & 88 & -14.5 & 81 & -0.011 & 91 \\
\hline 473 & 136 & 132.8 & 84 & 1.75 & 84 & 1.60 & 88 & 11.07 & 86 & 0.016 & 87 \\
\hline 31 & 109 & 244.1 & 83 & 2.48 & 88 & 1.02 & 86 & -118.4 & 72 & -0.004 & 84 \\
\hline 46244 & 89 & 99.1 & 93 & 3.57 & 87 & 2.52 & 86 & -15.5 & 84 & -0.068 & 79 \\
\hline 1124 & 73 & 223.0 & 84 & 5.03 & 86 & 2.56 & 81 & -177.7 & 79 & -0.013 & 84 \\
\hline 1090 & 70 & 117.4 & 78 & -4.74 & 80 & -2.32 & 95 & -81.4 & 81 & -0.028 & 82 \\
\hline & 5 & 116.2 & 79 & 11.87 & 93 & 8.13 & 79 & -20.95 & 86 & -0.009 & 73 \\
\hline 51441 & 40 & 640.1 & 73 & 11.81 & 92 & 9.03 & 68 & 29.35 & 72 & 0.004 & 54 \\
\hline & 30 & 193.4 & 76 & -3.11 & 72 & 1.91 & 72 & 13.03 & 72 & 0.028 & 71 \\
\hline & 36 & 375.3 & 77 & 11.06 & 67 & 9.64 & 72 & 10.91 & 46 & 0.004 & 46 \\
\hline & 28 & 326.9 & 67 & 7.51 & 84 & 5.92 & 49 & -24.07 & 64 & -0.009 & 71 \\
\hline & 20 & 400.8 & 64 & 9.97 & 58 & 8.60 & 57 & 12.16 & 37 & -0.009 & 49 \\
\hline WA & & 298 & 88.9 & 5.12 & 90.2 & 3.8 & 88.4 & -24.6 & 85.2 & -0.009 & 84.14 \\
\hline
\end{tabular}

* SireID = sire identification, ND = number of daughters and WA= weighted average.

\section{Accuracy of selection for resistance of mastitis}

Table (6) show comparison of the accuracies of selection for mastitis resistance when selection is based on SCC, or MAST or a combination of both with milk production using covariances and parameters estimated from the first lactation data. The accuracy of the index number (4) which included 
SCC, MAST with milk production was about 7 times higher than these for other indices and similar should be more efficient in improving mastitis resistance than direct selection on MAST. Other indices were nearly similar and close to those reported by Strandberg and Shook (1989). Results were reported by Philipsson et al., (1995) and Carlén et al., (2005) which confirmed considering SCC and MAST at a criterion for selection for mastitis resistance in the dairy cows.

Table (6): Accuracy ( $\left.r_{I H}\right)$ of selection for mastitis resistance based on different combinations SCC, MAST with milk production.

\begin{tabular}{|c|l|c|}
\hline Index & Traits in index & $\mathbf{r}_{\mathbf{I H}}$ \\
\hline 1 & MY, SCC & 0.55 \\
2 & MY, MAST & 0.60 \\
3 & SCC, MAST & 0.42 \\
4 & MY, SCC, MAST & 3.80 \\
\hline
\end{tabular}

\section{Conclusion}

Antagonism between udder health and production emphasizes the need to select for strong mastitis resistance to prevent the increase in the frequency of occurance mastitis as a consequence of selection for yield only. The moderate heritabilities of SCC $(0.08$ to 0.15$)$ and their high positive genetic correlation with MAST ( 0.72 to 0.83 ) make possible to use form as an indirect criterion to select against mastitis. The increased level of SCC and frequency of mastitis with parity and the high genetic correlations among inter lactations SCC (0.84 to 091 and MAST (0.71 to0.93) assured the necessity of adopting selection programme seeking the improvement of mastitis resistance early in the animal life and continues in all parities. Waiting for later lactations might create prolonged problems with respect to cow resistance to mastitis in later lactations while the latter should be improved if only the first lactation records were used.

When mastitis records are available, selection could be directly done against mastitis and informations on SCC could be used as a correlated trait when estimating EBV's. The high genetic correlations suggested a multi-trait model with first and/or later lactations to select against SCC and MAST. In addition, if informations on both traits are available, a combined evaluation will lead to more accurate prediction of breeding values for mastitis resistance.

\section{REFERENCES}

Banos,G., and G. E. Shook (1990). Genotype by environment interaction and genetic correlations among parities for somatic cell count and milk yield. J. Dairy Sci. 73:2563-2573.

Boettcher, P., A. Samore, and G. Pagnacco (2002). Relationship between normal levels of somatic cells and the duration of mastitis infections. Proc. $7^{\text {th }}$ World congr. Genet. Appl. Livest. Prod., Montpellier, France, CD-ROM communication No. 09-23.

Boichard, D., and R. Rupp (1997). Genetic analysis and genetic evaluation for somatic cell score in French dairy cattle. Proceedings International workshop on genetic improvement of functional traits in cattle; health. Uppsala, Sweden, June, 1997. Interbull Bull. 15:54-60. 
Boldman, K.G.; L.D. Van Vleck and S.D. Kachman (1995). A manual for use of MTDFREML. USDA-ARS. Clay Center, NE, USA.

Carlén, E., E. Strandberg, and A. Roth (2004). Genetic parameters for clinical mastitis, somatic cell score and production in the first three lactations of Swedish Holstein cows. J. Dairy Sci. 87:3062-3070.

Castillo-Juarez, H., P. A. Oltenacu, and E. G. Cienfuegos-Rivas (2002). Genetic and phenotypic relationships among milk production and composition traits in primiparous Holstein cows in two different herd environments. Livest. Prod. Sci. 78:223-231.

Charfeddine, N., R. A. Alenda, A. F. Groen and M. J. carabano (1997). Genetic parameters and economic values of lactation somatic cell score and production traits. Proceedings of the international workshop on genetic improvement of functional traits in cattle; health. Uppsala, Sweden, June 1997. Interbull Bull. 15:84-91.

Haile-Mariam, M., P. J. Bowman, and M. E. Goddard (2001a). Genetic and environmental correlations between test-day somatic cell count and milk yield traits. Livest. Prod. Sci. 73:1-13.

Haile-Mariam, M., M. E. Goddard, and P. J. Bowman (2001b). Estimates of genetic parameters for daily somatic cell count of Australian dairy cattle. J. Dairy Sci. 84:1255-1264.

Hansen, M., M. S. Lund, M. K. Sørensen, and L. G. Christensen (2002). Genetic parameters of dairy character, protein yield, clinical mastitis, and other diseases in the Danish Holstein cattle. J. Dairy Sci. 85:445452.

Heringstad, B., G. Klemestsdal, and J. Ruane (1999). Clinical mastitis in Norwegian cattle. Frequancy, variance components and genetic correlation with protein yield. J. Dairy Sci. 82-1325-1330.

Heringstad, B., G. Klemestsdal, and J. Ruane (2000). Selection mastitis resistace in dairy cattle: A review with focus on the situation in the Nordic countries. Livest. Prod. Sci. 64:95-106.

Kadarmideen, H. N. and J. E. Pryce. (2001). Genetic and economic relationships between somatic cell count and clinical mastitis and their use in selection for mastitis resistance in dairy cattle. Anim. Sci. 73:229-240.

Kehrli, M. E. and D. E. Shuster (1994). Factors affecting milk somatic cell and their role in health of the bovine mammary gland. J. Dairy Sci. 77:619627.

Koivula, M., E. A. Mäntysaari, E. Negussie and T. Serenius (2005). Genetic and phenotypic relationships among milk yield and somatic cell count befor and after clinical mastitis. J. Dairy Sci. 88:827-833.

Koivula, M., E. Negussie and E. A. Mäntysaari (2004). Genetic parameters for test-day somatic cell score (SCC) at different stages of lactation in Finnish Ayrshire cattle. Livest. Prod. Sci. 90:145-157.

Lassen, J., M. Hansen, M. K. Sørensen, G. P. Aamand, L. G. Christensen, and P. Madsen. (2003). Genetic relationship between body condition score, dairy character, mastitis, and diseases other than mastitis in first-parity Danish Holstein cows. J. Dairy Sci. 86:3730-3735.

Lund, T., F. Miglior, J. C. M. Dekkers and E. B. Burnside (1994). Genetic relationship between clinical mastitis, somatic cell count, and udder conformation in Danish Holstein. Livest. Prod. Sci. 39:243-251. 
Mäntysaari, E. A. (1999). Derivation of multiple trait reduced rank random regression (RR) model for the first lactation test day records of milk, protein and fat. Page 2 in Proc. 50 th Annu. Mtg. Eur. Assoc. Anim. Prod., Zurich, Switzerland, Wageningen Pers, Wageningen, The Netherlands.

Mrode, A. R., G. J. T. Swanson and M. S. Winter (1998). Genetic parameters and evaluations for somatic cell counts and its relationship with production and type traits in some dairy breeds in the United Kingdom. Anim. Sci. 66:569-576.

Mrode, R. A. and G. J. T. Swanson (2003). Estimation of genetic parameters for somatic cell count in the first three lactations using random regression. Livest. Prod. Sci. 79:239-247.

Nash, D. L., G. W. Rogers, J. B. Cooper, G. L. Hargrove, J. F. Keown and L. B. Hansen (2000). Heritability of clinical mastitis incidence and relationships with sire transmitting abilities for somatic cell score, udder type traits, productive life and protein yield. J. Dairy Sci. 83:2350-2360.

Nielsen, U. S., G. A. Pedersen, J. Pedersen, and J Jensen (1997). Genetic correlations among health traits in different lactations. Proceedings of the international workshop on genetic improvement of functional traits in cattle; health. Uppsala, Sweden, June 1997 Interbull Bull. 15:68-77.

Peeler, E. J., M. J. Green, J. L. Fitzpatrick and L. E. Green (2003). The association between quarter somatic cell counts and clinical mastitis in the three British dairy herds. Prev. Vet. Med. 59:169-180.

Philipsson, J. G., G. Ral and B. Berglund. (1995). Somatic cell count as a selection criterion for mastitis resistance in dairy cattle. Livest. Prod. Sci. 41:195-200.

Pösö, J. and E. Mäntysaari (1996). Relationships between clinical mastitis, somatic cell Score, and production in the first three lactations of Finnish Ayrshire. J. Dairy Sci. 79:1284-1291.

Rautala, H. (2002). Terveystarkkailun tulokset 2001. Nauta 32:48-49.

Rupp, R. and D. Boichard (1999). Genetic parameters for clinical mastitis, somatic cell score, production udder type traits, and milking ease in first-lactation Holsteins. J. Dairy Sci. 82:2198-2204.

Rupp, R. and D. Boichard (2000). Relationship of early first lactation somatic cell count with risk of subsequent clinical mastitis. Livest. Prod. Sci. 62:169-180.

Rupp, R., F. Beaudeau and D. Boichard (2000). Relationship between milk somatic cell counts in the first lactation and clinical mastitis. Prev. Vet. Med. 46:99-111.

Schutz, M. M., L. B. Hansen, G. R. Steuernagel, J. K. Reneau and A. L. Kuck (1990). Genetic parameters for somatic cells, protein and fat in milk of Holsteins. J. Dairy Sci. 73:494-502.

Shook, G. E. and M. M. Schutz (1994). Selection on somatic cell score to improve resistance to mastitis in the United States. J. Dairy Sci. 77:648-658.

Strandberg, E. and G. E. Shook (1989). Genetics end economic responses to breeding programs that consider mastitis. J. Dairy Sci. 72:2136.

Svensk Mjölk (2002). Husdjursstatistik (Cattle statistics), 2002. Svensk Mjölk (Swedish Dairy Association), SE-631 84 Eskilstuna, Sweden. 
Uribe, H. A., B. W. Kennedy, S. W. Martin, and D. F. Kelton. (1995). Genetic parameters for common health disorders of Holstein cows. J. Dairy Sci. 78:421-430.

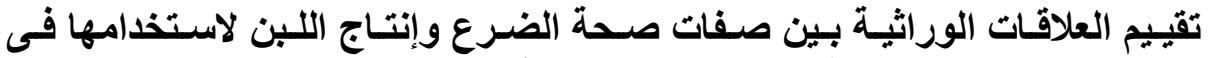

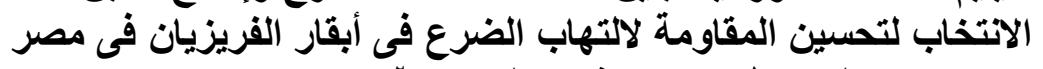

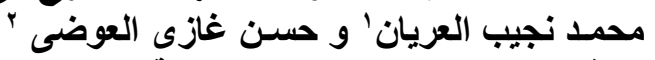

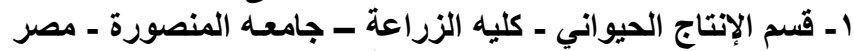

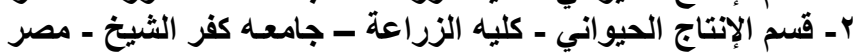

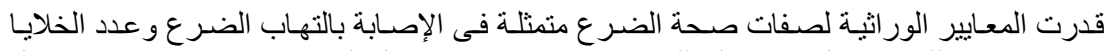

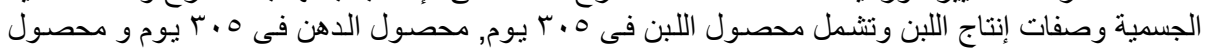

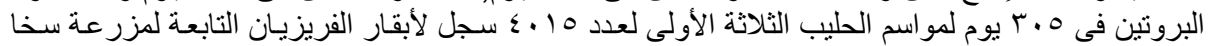

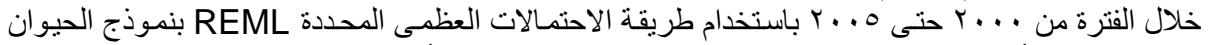

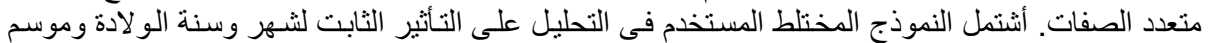

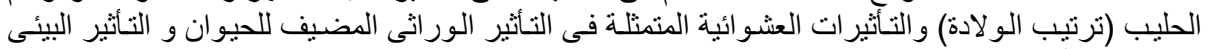

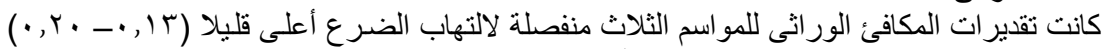

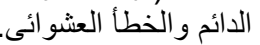

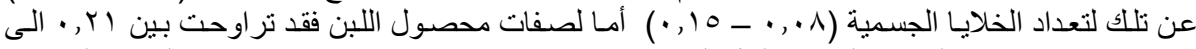

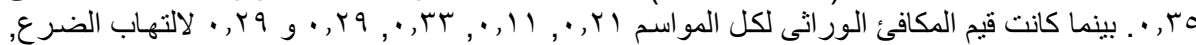

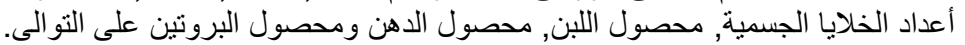

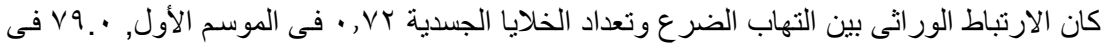

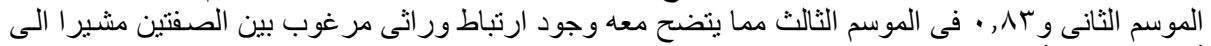

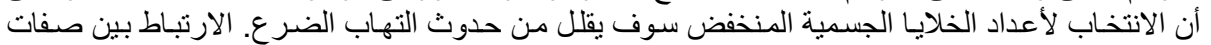

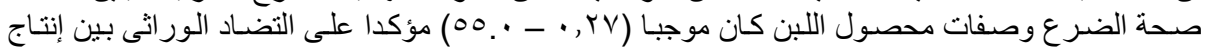

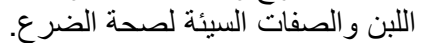

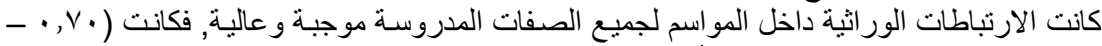

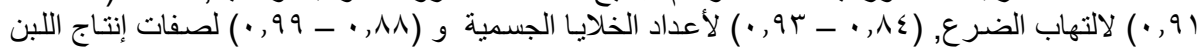

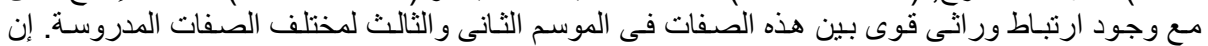

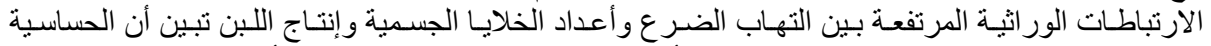

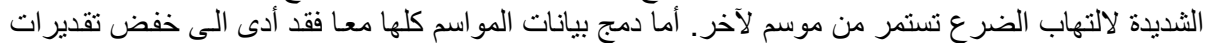

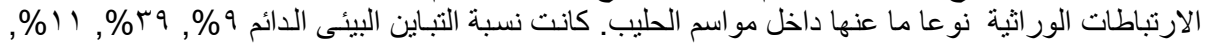

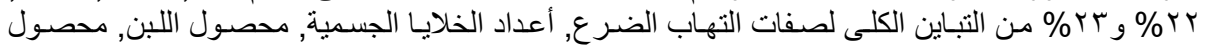

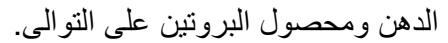

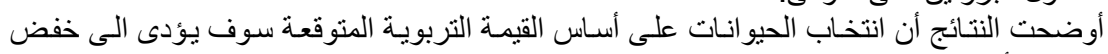

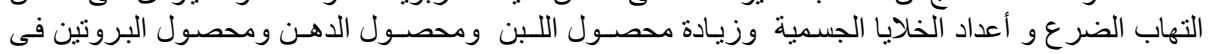

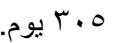

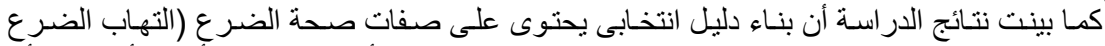

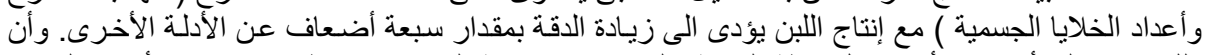

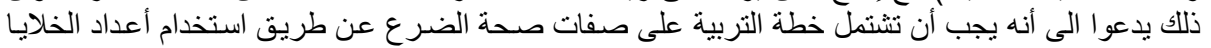

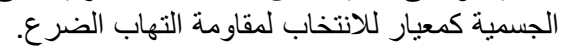

